\title{
Rasheed Oyaromade
}

Osun State University, Department of Economics, Osogbo, Nigeria rasheed.oyaromade@uniosun.edu.ng

\section{Olayinka Kehinde Binuomoyo}

Lead City University, Department of Economics, Ibadan, Nigeria

okbinuomoyo@gmail.com

\section{Akin George Ogunleye}

Osun State University, Department of Economics, Osogbo, Nigeria

akin.ogunleye@uniosun.edu.ng

\section{PERILS OF DEBT-FINANCING: EXTERNAL DEBT AND ITS IMPLICATIONS ON NIGERIA'S ECONOMIC GROWTH}

Received: August 1, 2021

Accepted: November 10, 2021

https://doi.org/10.46458/27121097.2021.27.94

\section{Preliminary communication}

\begin{abstract}
This paper examines the impact of external debt on the growth of the Nigerian economy between 1990 and 2018 with a view to drawing key implications for the management of the economy. Having ascertained that the variables of the study are non-stationary in levels but stationary after first differencing and also being cointegrated, error correction model (ECM) technique was used for the analysis. The pairwise Granger causality test results show that while a one-way causal relationship exists between fiscal balance and external debt with the causality running from fiscal balance to external debt, no causal relationship exists between external debt and real output. From the short run ECM and long run models, it was found that a statistically insignificant positive relationship exists between external debt and real output both in the short run and the long run. The statistical properties of the estimated ECM model show that the model is consistent, efficient and feasible for forecast and policy making. The recommendations that emanated from the study suggest that the Nigerian government should improve on fiscal policy governance, entrenching transparency and professionalism in
\end{abstract}


the management of the country's debt and that the larger public finance for debt should be made to be viable instrument for economic growth.

Keywords: Nigeria, External Debt, Economic Growth, Exchange Rate, ECM

JEL: F34, H6, H63

\section{INTRODUCTION}

Is debt a curse? Or, could debt be an impediment to economic growth? These questions and the likes often form the narratives of the African economies and development. But if debt is an undoing of the economies of developing countries, it is then worthy to start the narratives of this study with the question: are developing countries averse to foreign financing? Or, are these economies better off when 'free' foreign financing as aids are made available? The Nigerian case is put forward to help investigate how external debt impact the economy.

Economic growth is defined as a sustained and quantitative increase in per capita income, consumption, capital and volume of trade in a specific country over a period of time, whereby growth is linked with the expansion in output only, while economic development captures increase in output and changes in the economic structure (Jhingan, 2000).

Economic growth is first of all a function of input of which capital is principal. In view of this, external debt as a source of capital can be related to economic growth. But while external debt affects growth either positively or negatively, its utilisation will significantly determine its impact on the economy. Economic growth is catalysed by investment, which is further reinforced by external funding to complement public investment by government. External financing in forms of external debt and foreign aids have constituted significant portion of government financing for most sub-Saharan African countries irrespective of whether they are resource dependent or not.

The effect of external public debt is a concern for researchers and policy makers. Given Nigeria's unending romance with public debt, it is imperative to understand how external debt may impact economic growth of the country. That is, what empirical evidence occurs therein, on the relationship between external debt and economic growth? In the overall, it is important for a total macroeconomic policy to be put in place to manage the debt, and this needs to be coordinated meticulously along with fiscal, monetary and other macroeconomic policies (Saifuddin, 
2016). Deficit budget with respect to public expenditure and global interest rate are outlined as determinants of foreign loans accumulation (Edo, 2002).

Divergent views exist among researchers and public economic commentators on whether financing government expenses through debt is good or bad for the country's economy. While debt is a good way to increase growth through capital accumulation and productivity growth, it is not absolutely beneficial (Chowdhury, 2001). According to Perlo-Freeman and Webber (2009), while some macroeconomic theories posit that public expenditure has a positive impact on growth through its productive impact on education and health with resulting long-term economic returns, it may lead to leakages from mismanagement. And where public expenditure is debt-financed, it amounts to greater loss for the economy. Looking beyond the negatives, Chowdhury (2004) demonstrated that a relationship indeed exists between foreign debt and economic growth for most countries, with some authors advancing the growth-with-debt theory which supports the thesis that there is a relationship between external debt and economic growth (Greene and Khan, 1990).

The debate on the impact of external debt on economic growth is exemplified in the cases of developing countries, with deductions that it could be positive, negative, or no significant relationship for diverse economic situations and a number of dissimilar countries. In Nigeria for example, the ratio of external debt to gross national income (GNI) ranges from $14.63 \%$ to $4.21 \%$ between the periods 1980 to 2012 , with debt service ratio reducing from $1.88 \%$ in 1980 to $0.12 \%$ in 2012 (Central Bank of Nigeria [CBN]). For most developing countries, the option to address their capital inadequacy is to employ foreign savings to enhance the stock of capital over savings, especially for planned development projects and programmes.

The rising debt profile of Nigeria, both domestic and foreign, is a major cause of concern to both researchers and economic policy analysts. But the quest for growth and development in developing countries has overshadowed these concerns. Nigeria in particular has low capital formation due to the low levels of savings and investments and has resorted to both domestic and external borrowings in order to augment the available capital to meet up with development demands (Adepoju, et al., 2007). After the global financial meltdown of the 2007/8, Nigeria's debt burden went up, surpassing $100 \%$ of the country's gross domestic product (GDP). The debt profile has been worsened by the deteriorating economy of the country and the subsisting economic recession.

Nigeria's historical debt spanning over three decades provides the basis to analyse how the debt burden has impacted the country's economy. The consequence 
of the debt problem was brought to the fore between 2000 and 2007 when the government sought debt pardon from the Paris and London Club of Creditors in order to ameliorate the negative impact it had on the country's economy (CBN, 2014). ${ }^{1}$ Nigeria's external debt stock stood at US $\$ 15.35$ as at mid-year 2017, but had risen to US $\$ 21.59$ billion in the fourth quarter of 2018, and then US $\$ 25.61$ billion in the first quarter of 2019 from, with the debt averaging US \$9.63 billion from 2008 to 2019, reaching an all-time high of US \$29.59 billion in the third quarter of 2018, from a record low of US $\$ 3.63$ billion in the first quarter of 2009 (Rafindadi and Musa, 2019).

A large body of works has explored the relationship between national debt and economic growth in Nigeria, with much of the research focusing on external and debt-economic growth relationship (Adedoyin, et al., 2016; Abdullahi et al., 2015; Adegbite et al., 2008; Adepoju et al., 2007; Audu, 2004; Ajab and Audu, 2006; Ezeabasili et al., 2011; Udoffia and Akpanah, 2016). The outcome has always been that foreign debt has added so much value to the economy with direct effects on foreign exchange reserves and the strength of the currency, with the ultimate impact on growth.

Indeed, Nigeria has a long significant history of foreign indebtedness which predates the pre-independence era, though the debt burden was somewhat insignificant as at the 1970s which consisted of mostly long-term credits from multilateral and official loan sources like the World Bank, the International Monetary Fund (IMF) and Nigeria's major trading partners, with softer terms but less significant on the country's economy, as the vast revenue receipts from oil especially during the oil boom of the 1970s were adequate to absorb the adverse effect of the debt burden on the Nigerian economy (Debt Management Office [DMO], 2012; Udoka, and Ogege, 2012). The Nigerian Debt Management Office in its 2014 annual report noted that bilateral loans consisted of credits issued by China and France on semi concessionary terms, and these were in the range of US \$1.03 billion and US $\$ 1.4$ billion by the respective year-end 2013 and 2014 , with the multilateral loans in the figure of US $\$ 6.8$ billion, which was around $70 \%$ of the total external debt portfolio of the country in 2014 (DMO, 2015).

\footnotetext{
1 The debt burden of Nigeria was as much as US \$18 billion in 2005 aside accrued interest, with the country ranking as the largest debtor nation in sub-Saharan Africa (SSA). But then, the external debt situation has relapsed after the Paris Club debt write-off deal in 2005 which was completed in April 2006, with the external outstanding debt put at US \$4 billion (as at when US \$12 billion was paid off, while US \$18 billion was written off) in 2006 and over US \$1 billion in 2012 respectively (Dijkstra, et al., 2011). The outstanding external debt level for Nigeria was US $\$ 9.7$ million at the end of December 2014, compared to US $\$ 8.8$ billion at the end of 2013 (see CBN, 2014).
} 
Given the scarcity of capital faced by developing countries and its implications, it is important to note that the debt problem of these countries started with the quest for investment which never came as expected, and the appetite for social and infrastructural development to create a competitive economy. Hence, the resort to external borrowing in order to augment domestic savings and investment (Safdari and Mehrizi, 2011). And of course, it has been established that nations borrow for two broad reasons: macroeconomic, in order to finance higher level of consumption and investment, and to finance transitory balance of payment deficit and circumvent budget constraint in order to boost economic growth and reduce poverty (Soludo, 2003).

The role of external debt in an economy like Nigeria with low domestic investment cannot be overemphasized as among other things, it enhances total factor productivity through an increased output which as a result, boosts the growth of the country's gross domestic product (GDP), with far-reaching impact in improving the living standards thereby alleviating poverty. External borrowing is anticipated to enhance economic growth particularly due to inadequacy of domestic financing. So, foreign debt as a primary source of public receipts and financing, addresses fiscal deficits; was created to meet the continual needs of governments to borrow so as to finance budget deficits (Adepoju et al., 2007). It is a platform employed by countries to bridge their fiscal deficits and execute economic projects that can enhance the living standard of the people, as well as promote sustainable growth and development.

Economic growth is negatively affected by high debt level in developing countries with countries like Nigeria heaping up a large sum in external debt, and the accumulation of debt service repayments which could have resulted from missed loan repayments or defaults, often resulting in problems for the developing countries as penalties rise along with running interest rates on the unpaid loans, thereby slowing down growth as available funds for the country are used for non-productive purpose (Mutasa, 2003; Gohar et al., 2012). The Nigerian situation is such that it has accumulated debt repayments which it is unable to service adequately thus resulting in debt overhang that continues to militate against its growth and development (Audu, 2004).

This study examines the impact of external debt on the growth of the Nigerian economy between 1990 and 2018 with a view to drawing key implications for the economy. The administration of the country's fiscal structure as it concerns budget and debt was also examined. Following the introduction is the literation review that contains both theoretical and empirical review. Section three presents the methodology and data for the study while section four presents the analysis and discussion of results from the estimation of the model for the study. The last 
section concludes the paper and proffers some recommendations to ensure optimal external debt procurement and debt servicing sustainability.

\section{LITERATURE REVIEW}

\subsection{Theoretical Literature}

\subsubsection{The Solow growth model}

Solow's neoclassical model of economic growth relies on the expansion in savings and investments, which means that developing countries must formulate policies that enhance savings which will then increase investment, and hence growth (Solow, 1956). In line of this, for a country to finance its activities, it utilizes either internal sources such as fees and taxes, or resort to borrowing in order to augment internally sourced funds to finance the budget deficit. The neoclassical growth theory establishes that debt has a positive direct impact on economic growth, with the justification that if the borrowed funds are optimally put to good use, there is a great probability of increased investment, while the indirect effect of debt is its effect on investment, through channelling of new capital into the economy. The transmission mechanism through which debt affects growth is its reduction on the resources available for investment due to debt servicing.

\subsubsection{Dual gap theory}

Adegbite et al. (2008)'s discussion of the dual gap theory help explains the reason why most governments prefer external financing to domestic borrowing which is because developing economies do not possess the level of domestic savings that are sufficient to finance the needed investment for economic development. These countries hence resort to external borrowing if it is expected that the returns on the borrowed funds will be higher than the actual borrowing cost. It is understood that external debt does not immediately lead to a debt burden once it is optimally utilised. And according to Adegbite et al. (2008), at optimal level, the marginal return on investment is higher than or equal to the borrowing cost, and in this instance, debt will positively impact growth. 


\subsubsection{Debt overhang hypothesis}

The debt overhang theory shows the possibility of a country's debt being greater than its ability to repay in the future, consequently, expected debt repayment costs will discourage further domestic and foreign investment because the expected rate of return from the productive investment projects will be very low to support the economy as the significant portion of any subsequent economic progress will accrue to the creditor country which will eventually further reduce both domestic and foreign investments and hence downsizes economic growth (Krugman, 1988; Sachs, 1989). Claessens and Diwan (1990)'s further explanation of the debt overhang theory sees it as a situation in which the illiquidity effect and the disincentive effect are strong enough to discourage growth in the absence of concessions by creditors.

According to debt overhang hypothesis, a specific level of external debt has a direct positive impact on economic growth until a certain point whereby a marginal debt (added) will negatively affect growth. In effect, debt servicing, that is, repayments of principal and accrued interests may be a real deal for an indebted country, in that it takes large benefits from the domestic economy, which are transferred to the foreign economy (creditor), making the country to forego certain multiplier-accelerator effects, and in the process increasing the domestic economy's dependence on external debt and reducing its ability to grow (Metwally and Tamaschke, 1994).

The literature on debt overhang hypothesis and its effects on growth has shown that debt relief may be able to stimulate investment and enhance economic growth. Knowing that debt overhang exists in a situation where a country exceeds its repayment ability, Krugman (1988) and Sachs (1989) submit that expected debt repayment is an increasing function of country's output level. Hence in debt overhang, the higher percentage of benefits of an increased output engineered by debt financing goes to the creditor while all the costs incurred go to the debtor country. In the overall, debt overhang of high debt reduces both public and private investments, while it's also a disincentive to reforms (Corden, 1998; Johansson, 2010).

\subsubsection{Crowding-out effect}

The crowding out effect as an economic theory argues that as public sector spending rises, private sector spending is driven down or eliminated. It is an occurrence that takes place when increased government intervention in a sector of an economy significantly affect the other parts of the economy, either on the demand 
or supply side of the market, with expansionary fiscal policy that reduces investment spending of the private sector, such that government spending 'crowds out' investment because it is demanding more loanable funds and thus causing increased interest rates with consequent reduction in investment spending. It can also be explained as a situation where personal consumption of goods and services as well as investments by businesses are reduced because of increased government spending and deficit financing lapping up available financial resources and raising interest rates.

With crowding out, a government embraces an expansionary fiscal policy measure whereby it increases its spending to boost the economic activity by increasing its borrowing leading to a considerable rise in the real interest rate, with the attendant effect of absorbing the economy's lending capacity and discouraging businesses from making capital investments, as such reduces private investment whereby it dampens the initial increase of total investment spending. And due to the fact that firms often partly fund such projects, or wholly through debt financing, they are not encouraged to do so because the opportunity cost of borrowing money rises following increased rates, making conventionally profitable projects funded through loans cost-prohibitive. The reduced investment ultimately crowds out the impact of the initial rise in the total investment spending, which was funded using higher taxes or borrowing on the part of the government.

In summary, the following general reflections were shared by Chowdhury (2001), Perlo-Freeman and Webber (2009), Chowdhury (2004) and Greene and Khan (1990) which constitute part of key take-aways from this theory and of course, its implications for the country's debt:

- the crowding-out effect is driven by three-way public sector foci: economics, social welfare, and infrastructure, which are the main thrusts of government fiscal spending;

- while it submits that increased public sector spending pushes down private sector spending, this can affect liquidity and investment drive in the country particularly because government is competing for funds against the private sector, which might not be market determined; and

- in contrast to crowding-out, crowding in, is when public sector borrowing actually increases demand by creating employment, hence stimulating private spending.

Aluko and Arowolo (2010) noted that in developing countries and particularly sub-Saharan Africa (SSA), external debt seems to impact differently, and this 
might be traceable to mismanagement. We must understand that debt lag is technically a big economic factor as previous debt situation also impacts the economy as much as current debt.

\subsection{Some Previous Thoughts}

Economic growth in the pre-1970s was generally high for most developing countries, and are led by primary industries particularly agriculture, with adequate local investments in economic and social infrastructures like roads and transports, power, institutional structures, stadiums, and so on. The Nigerian example saw investments in the north of the country led by its pyramidal groundnut business, the south-east was heavily involved in the oil palm business and the south-west was developed from the hugely successful cocoa farm business leading to the building of structures like university and other schools (including the provision of free education), roads and railway transports, stadium, television, stadium, as well as other social investments.

The 1970s saw great rises in oil price following the Middle-East war and induced market action of the Organisation of Petroleum Exporting Countries (OPEC) which was matched with a reactional market activity from the western markets leaving the developing countries with deficit balance of payment issues created by the shock in the increase in oil price and imported products' prices especially for the import dependent and non-resource based economies.

Broadly speaking, this paper fits into the available research studies on the relationship between foreign or external debt and economic growth. A lot of interests have gone into this area of research. Firstly, there had always been a need by countries to borrow due to inadequate savings for productive engagements. (Ezeabasili, 2011). Udoffia and Akpanah (2016) emphasised that these borrowings can be for long run such as those required to complement domestic savings and borrowings, and could be for short term, for the financing of current account deficits emanating from external disturbances so as to increase the position of external reserves and reinforce external liquidity position in the future.

Second, historical patterns of the effect of debt on the economies of countries have shown that debt accumulation does have adverse consequences especially for economies of developing countries. The classic examples in Mexico and Argentina are just the perfect (Ezeabasili et al., 2011). Indeed, low debt levels or budget deficits were more probable to create positive impacts on public expenditure, while high levels of public debt lead to negative impacts (Perotti, 1999; Alfredo, 2002), following from investigation of the relationship among fiscal deficits, public debts, and economic growth in emerging markets. Reduced total 
external debt levels were associated with higher growth rates, with the resulting negative relationship driven by the incidence of public external debt levels, and not by private external debt levels (Davidson and MacKinnon, 2004).

The reason for a negative correlation between foreign debt and economic growth has a relationship with the debt overhang effect, as a large debt liability squashes investment, due to the fact that returns are drained away by external creditors (Cohen, 1993). It was also established that the debt-growth relationship follows a bell-shaped curve beyond a certain debt ratio, consequently, the impact of the external debt stock on growth becomes negative (Clements et al., 2003). This was also demonstrated in that the marginal impact of external debt on economic growth in developing countries turns negative per the net present value (NPV) of debt ranging between 0.05 and 0.50 point of the GDP (Pattillo et al., 2002; Pattillo et al., 2004).

Third, the impact of external borrowing can be explained in the public investment pool and economic growth it brings a nation, even though a high level of external debt could mean much debt servicing which could erode off funds and affect the economy. Certain authors have also maintained that while debt may indeed be good, it is only a low level of it that has positive effects on the growth of a country (Pattillo et al., 2002). Expanding on the above submission, Fosu (2007, 2009) noted that a high debt repayment by government shift spending away from the provision of social services like health and educational, which defeats the purpose of incurring such debt as boosting growth and development.

Fourth, the flow of debt affects economic performance in a situation described as crowding-out effect, whereby a decrease in current debt burden and debt service raises the current level of investments, for any given level of future debt, ${ }^{21}$ though contrary opinion is that significant presence of crowding-out effect could not be substantiated (Pattillo et al., 2002; Pattillo, et al., 2004). It was confirmed that a drop in debt service from $8.7 \%$ to $3 \%$ of GDP will lead to an increment in public investment by about a range of $0.7 \%$ to $0.8 \%$, and this improved investment will result in a per capita GDP growth increase of between $0.1 \%-0.2 \%$ (Clements et al., 2003). But then, some authors believed that debt stock rather than its flow affects economic performance, as a result of uncertainties associated with the level of external debt (that is, high and volatile inflation, as well as interest rates), which decreases the efficiency and productivity of capital, resulting in a reduced speed of economic growth (Moss and Chiang, 2003).

2 Here, the thoughts of Chowdhury (2004), Clements et al. (2003) and Elbadawi et al. (1997) were reflected in the relationship between debt level and investments. 
Lastly, a study on fiscal consolidations by Giavazzi and Pagano (1990) in Denmark and Ireland in the 1980s showed that in these two countries, a decline in public deficit leads to a sharp rise in private consumption, and a confirmation of this by Borensztein (1990) using the debt overhang effect with the case of the Philippines, discovered that the debt overhang hypothesis was mostly valid, as the debt overhang negatively affected private investment. Also, Ndung'u,(1998) relying on the empirical work of Elbadawi et al. (1997) investigated the dynamic effect of foreign debt accumulation on private investment and growth in Africa, with a conclusion that the external debt problem in Africa has resulted in an investment break and has resulted in a substantially reduced growth performance.

The standard logic of borrowing is that countries could take on foreign debt in as much as the capital accessed will lead to the production of a rate of return that is greater than the borrowing cost; and in this case, the borrowing countries increase their productive capacity and expand output with the aid of external savings, while also helping the borrowing countries' economies to produce a multiplier effect that resulted in substantial infrastructure, better exchange rate, a big export market, increased employment, and positive terms of trade growth (Hameed et al., 2008). Several authors have made basic insights into the theories that explain external debt and economic growth relationship, with the fact that foreign resources in the forms of aids, grants and loans to developing countries are crucial to transforming these countries and creating sustainable growth for them. ${ }^{3}$

Public expenditure is constrained by government budget, budget deficits, government spending and revenues (principally taxes). Empirically, government debt could be described as a function of the budget, economic performance and of course, the revenues. This is a general relationship. For developing countries, it could be reasonable to introduce a governance variable with strong government influence that include leakage variable (corruption), mismanagement (that could be as a result of poor skill and technical expertise in economic management and nepotism), and a generally out of the shape economy.

\subsection{Nigeria and macroeconomic level debt relativity}

In the 1970s, Nigeria was self-sufficient with oil exports in excess of the budgetary requirements. Like other nations, in its quest to bite harder and improve infrastructure, and tempted with the much available and cheap international loans, Nigeria sojourned into the external debt borrowing terrain in the $1980 \mathrm{~s}$

\footnotetext{
3 Domar (1987), Higgins (1959), Pearson (1969), Symonds (1970) and Chenery (1966)'s works resolved that foreign resources enhances not just growth, but sustainable one, and contribute to the development of the recipient countries.
} 
and thereafter notwithstanding a pile up of domestic debts, low savings and investments, huge current account deficits and oil price volatility dropping below budget benchmark, in the midst of an increasing knack for foreign made products and services.

In 2005, Nigeria experienced a debt pardon deal that saw the Paris and London Clubs of Creditors forgiving Nigeria's sizeable debt in a landmark relief which amounted to the accrued interests only while the country paid off the principal loan. But the pre-2005 debt experience had seen the negatives: economic dependence, high debt service ratio, poor investment rating and a consequent low investment patronage. The lesson was not learnt as the country is today back at the previous situation of very high external debt and debt servicing burden.

Nigeria's foreign debt which dates back as far as half century following a US \$28 million foreign loan utilized in constructing the first rail line project in the country has been chronicled by Abdullahi et al. (2015). The 1978 oil price collapse resulted in budget deficits which forced the government into taking more foreign loans to cover the gap and by 1980, the country's debt has grown to US $\$ 4.6$ billion, and US \$32.9 billion in 1990 following a combined economic issues that included exchange rate devaluation and an unfavourable policy environment (Ajab and Audu, 2006; Abdullahi et al., 2015). The negativities of external debts accumulation to which high interest rates, persistently depreciating exchange rates and huge budget deficits are included have been well documented as well (Abdullahi et. al., 2015). The debt and the inability to service repayments became an overhang and choked the country to the extent that it grew to as high as US $\$ 30$ billion in 2005 . This led the country to seek a way out following a brief period of oil boom, that helped to see to the exit from the London and Paris Club of Creditors in 2006 following a pardon of US \$18 billion, and a repayment of US $\$ 18$ billion in actual debt (constituting 60\% of debt relief), and a positive impact on the GDP (DMO, 2015).

The burden of Nigeria's debt service dates back to as far as 1978 when it secured a facility of US\$ 1 billion from the International Capital Market (ICM) following a fall in global prices of oil, even though the country had incurred lesser external debts from the World Bank in 1958 with a loan of US\$28million dollars for railway construction project as well as the Italian government and the Paris Club of Creditors amounting to US\$13.1 million for the construction of the Niger dam (Adesola, 2009).

Debt financing though has its merit and has played significant role in Nigeria's growth efforts, some indications have however shown that in terms of real GDP growth, external debt does not seem to have positive impact as shown in the 
country's public economic accounts where with a debt stock of less than US $\$ 20$ billion in the years 2006 to 2010 , the country's economic growth steadily rose from $6.7 \%$ to $11.3 \%$, during which was during the first decade of Nigeria's democratic experience (CBN, 2012; World Bank, 2019a,b). But with increasing debt stock from 2011, coupled with the poor quality of governance (much better explained by the country's rising corruption index), economic growth declined to as low as $-1.6 \%$ in 2016 , when the debt stock rose to US $\$ 31.2$ billion (AfDB, 2019; Transparency International, 2019; World Bank, 2019a,b). ${ }^{4}$

Nigeria, like other developing countries require massive funding to activate its development plans and actualize its goals. Thus, the resort to huge borrowings by the government from multilateral channels resulting in a high external debt and repayment burden, so that the country was thereafter classified as heavily indebted. Nigeria's external debt rose from the 1997 figure of US \$28.5 billion to US $\$ 39.9$ billion in 2004 representing 52.58 percent of GDP. The huge debt repayment by the country left large fiscal deficits with significant consequences on the economy which included crowding out of private investments, poor GDP growth, low public expenditure, and so on (Omoh, 2011).

\section{METHODOLOGY AND DATA}

\subsection{Data}

This study employed basically secondary data which are annual time series data for the period 1990 to 2018 obtained from official data sources like the World Bank, African Development Bank (AfDB), and other statistical sources. We also adopted the World Bank's Country Policy and Institutional Assessment (CPIA) to represent public sector governance of finance, economy and the associated trust level of this sector.

\subsection{Model specification}

In this section, we evaluate the economic impact of external debt where debt comes in as financial investment but not matched by active engagement of the funds. For a steep economy, external debt could also be in form of leakage from the economy so that it slips out freely out of the economy. In any of these, we could deduce that external debt affects economic growth. Hence, we examine the impact of every increase in external debt on economic growth, taking into

4 Critical data sources are credited to www.opendataforafrica.org, www.worldBank.org; and www.AfDB.org. 
consideration the interaction of inflation rate, real effective exchange rate, fiscal balance and other factors captured by the CPIA.

In general form, the growth equation for the study is specified as:

$R G D P=f((E X D T, F I S B, I N F L, R E X R, C P I A)$

Re-specifying equation 1 in econometric form, we introduce the error term while also taking the log of real GDP.

$\operatorname{InRGDP}=\delta_{0}+\delta_{1} E X D T+\delta_{2} F I S B_{t}+\delta_{3} I N F L+\delta_{4} \operatorname{In} R E X R+\delta_{5} C P I A+\mu(2)$

Where $\delta_{0}$ is the intercept, $\delta_{1}$ to $\delta_{5}$ are the coefficients of the explanatory variables, while $\mu$ is the random error term with the assumption of identical and independent distribution of the residuals. 'In' represents natural log of the subsisting variable pre-named to it.

The expected behaviour of the independent variables (or, the a priori expectations) on the dependent variable are stated as follows, such that the inflationary rate (though, the coefficient of inflation is ambiguous and can take either positive or negative value), total stock of external debt and past debt accumulation are expected to impact negatively on economic growth. The coefficients of fiscal balance, CPIA and real exchange rate are expected to be positive in the growth equation. Country policy on institutional assessment reflect the positive impact of the public sector in terms of a gamut of characteristics including fiscal and debt policy management, transparency, accountability, and corruption with a rating from 1 (low) to 6 (high).

Further explanations of the variables are given in Table 1. 
Table 1 Definition of variables and related concepts

\begin{tabular}{|c|c|c|c|}
\hline $\mathrm{S} / \mathrm{N}$ & Variables & Definitions & Source \\
\hline 1 & $\begin{array}{l}\text { Real GDP } \\
\text { Growth (RGDP) }\end{array}$ & $\begin{array}{l}\text { Growth in real gross domestic product is the annual } \\
\text { percentage growth rate of the gross domestic product } \\
\text { (GDP) at constant prices. }\end{array}$ & WDI \\
\hline 2 & $\begin{array}{l}\text { External Debt } \\
\text { (Total external } \\
\text { debt) }\end{array}$ & $\begin{array}{l}\text { Total external debt is debt owed to non-residents } \\
\text { repayable in currency, goods, or services. Data are } \\
\text { in current U.S. dollars. External debt Stock is the } \\
\text { amount at which the debt was contracted and it is } \\
\text { used as a proxy for capturing external debt burden. }\end{array}$ & WDI \\
\hline 3 & Fiscal Balance & $\begin{array}{l}\text { Fiscal balance is the government budget balance, that } \\
\text { is, the difference between government's total rev- } \\
\text { enues and total expenditures. }\end{array}$ & WDI \\
\hline 4 & Inflation Rate & $\begin{array}{l}\text { Inflation as the growth rate of the consumer price in- } \\
\text { dex (CPI). }\end{array}$ & WDI \\
\hline 5 & $\begin{array}{l}\text { Exchange rate } \\
\text { index }\end{array}$ & $\begin{array}{l}\text { Exchange rate is the price of a nation's currency in } \\
\text { terms of another currency. }\end{array}$ & WDI \\
\hline 6 & $\begin{array}{l}\text { Country Policy } \\
\text { Institutional As- } \\
\text { sessment CPIA) }\end{array}$ & $\begin{array}{l}\text { CPIA is measured in terms of transparency, account- } \\
\text { ability, and corruption in the public sector with rating } \\
\text { of } 1 \text { (low) and } 6 \text { (high). Transparency, accountability, } \\
\text { and corruption in the public sector assess the extent } \\
\text { to which the executive can be held accountable for its } \\
\text { use of funds and for the results of its actions by the } \\
\text { electorate and by the legislature and judiciary, and the } \\
\text { extent to which public employees within the execu- } \\
\text { tive are required to account for administrative deci- } \\
\text { sions, use of resources, and results obtained. }\end{array}$ & WDI \\
\hline
\end{tabular}

Source: Authors' compilation.

\subsection{Model estimation technique and procedure}

The correlation and covariances of the variables are first analysed followed by the test for stationarity which was done using both the Augmented Dickey Fuller (ADF) and Phillips-Peron statistics. Cointegration test was also carried out on the variables having confirmed that the variables are integrated of different orders. We use pairwise Granger causality test to examine the causal relationship among the variables of the study to provide preliminary relationship among the variables. The long run model of the study was also estimated as a prelude to the estimation of the short run error correlation model (ECM). The statistical properties of the estimated short run ECM were examined and analysed accordingly. 


\section{RESULTS: ANALYSIS, INTERPRETATION AND DISCUSSION}

This study employs time series data spanning 1990 to 2018 and the empirical analysis begins with the examination of the covariance and correlation analysis of the variables included in the model. This is presented in Table 2.

Table 2 Covariance and correlation analysis

\begin{tabular}{cl|c|c|c|c|c|c|}
\hline Variable & & CPIA & EXDT & FISB & INFL & LRGDP & REXR \\
\hline CPIA & Covariance & 0.022 & 7 & \\
\hline & Correlation & 1.000 & 7 & & & \\
\hline EXDT & Covariance & 0.994 & 75.82 & & & & \\
\hline & Correlation & -0.775 & 1.000 & & & & \\
\hline FISB & Covariance & -0.085 & 0.326 & 12.666 & & & \\
\hline & Correlation & -0.162 & 0.011 & 1.000 & & & \\
\hline INFL & Covariance & -0.863 & 40.53 & 7.279 & 284.20 & & \\
\hline & Correlation & -0.347 & 0.276 & 0.121 & 1.000 & & \\
\hline LRGDP & Covariance & 0.041 & -1.337 & -0.605 & -3.733 & 0.233 & \\
\hline & Correlation & 0.577 & -0.318 & -0.352 & -0.459 & 1.000 & \\
\hline REXR & Covariance & -0.208 & 11.749 & -29.998 & -15.525 & -1.128 & 2607.3 \\
\hline & Correlation & -0.028 & 0.026 & -0.165 & -0.018 & -0.046 & 1.000 \\
\hline
\end{tabular}

Source: Authors' computation from E-Views 10 (2020). Variables are as defined in Table 1.

As shown in Table 2, external debt is positively correlated with fiscal balance, inflation and exchange rate while it is negatively correlated with output, i.e. the $\log$ of real GDP. Fiscal balance is negatively correlated with output and exchange rate but positively correlated with inflation. Inflation is found to be negatively correlated with both output and exchange rate while the Country Policy on Institutional Assessment (CPIA) indicator has negative correlation with virtually all other variables except output. The covariance analysis shows the variables are not widely disperse from each other. 
Table 3 Stationarity test

\begin{tabular}{cccccc}
\hline Variables & $\begin{array}{c}\text { ADF } \\
\text { (Intercept } \\
\text { only) }\end{array}$ & $\begin{array}{c}\text { ADF } \\
\text { (Intercept } \\
\text { \&trend) }\end{array}$ & $\begin{array}{c}\text { Phillips- } \\
\text { Peron } \\
\text { Intercept } \\
\text { only) }\end{array}$ & $\begin{array}{c}\text { Phillips- } \\
\text { Peron } \\
\text { (Intercept \& } \\
\text { trend) }\end{array}$ & Decision \\
\hline EXDT & -1.959 & -0.754 & -1.215 & -1.073 & $\mathrm{I}(1)$ \\
$\Delta$ EXDT & $-3.776^{* *}$ & $-3.934^{*}$ & $-3.668^{*}$ & $-3.808^{*}$ & $\mathrm{I}(0)$ \\
FISB & $-4.295^{* *}$ & $-4.707 * *$ & $-4.276^{* *}$ & $14.683^{* *}$ & $\mathrm{I}(1)$ \\
$\Delta$ FISB & $-6.026^{* *}$ & $5.939 * *$ & $-23.70^{* *}$ & $-23.574 * *$ & $\mathrm{I}(0)$ \\
INFL & -2.000 & -2.638 & -2.258 & -2.838 & $\mathrm{I}(1)$ \\
$\Delta$ INFL & $-4.274 * *$ & $-4.339 * *$ & $-4.234 * *$ & $-4.193 * *$ & $\mathrm{I}(0)$ \\
LRGDP & -0.932 & -1.902 & 0.076 & -2.103 & $\mathrm{I}(2)$ \\
$\Delta$ LRGDP & -2.260 & -2.046 & -2.254 & -2.013 & $\mathrm{I}(1)$ \\
$\Delta \Delta$ LRGDP & $-5.964 * *$ & $-4.789 * *$ & $-5.904 * *$ & $-6.005 * *$ & $\mathrm{I}(0)$ \\
REXR & -2.408 & -2.363 & -2.559 & -2.508 & $\mathrm{I}(1)$ \\
$\Delta$ REXR & $-4.913 * *$ & $-4.841^{* *}$ & $-4.913 * *$ & $-4.839 * *$ & $\mathrm{I}(0)$ \\
CPIA & -1.763 & -1.460 & -1.776 & -1.503 & $\mathrm{I}(1)$ \\
$\Delta$ CPIA & $-5.440 * *$ & $-5.528^{* *}$ & $-5.440 * *$ & $-5.529 * *$ & $\mathrm{I}(0)$ \\
\hline
\end{tabular}

Source: Authors' computation from E-Views $10(2020)$. The asterisks $* *$ and $*$ denote the significance levels at $1 \%$ and $5 \%$ respectively. $\Delta=$ First difference operator; $\Delta \Delta=$ second difference operator; critical values (intercept only): $1 \%=-3.700, \quad 5 \%=$ -2.976 ; and critical values (intercept with trend): $1 \%=-4.324,5 \%=-3.581$

To ascertain the order of integration of the variables for the study, the Augmented Dickey Fuller and the Phillips-Peron statistics were employed. Testing for stationarity in econometrics is essential to be able to determine the appropriate estimation technique that will be used for the study. If all the variables are stationary i.e. I(0), it will be in order to use OLS; however, when the variables are not stationary in levels and exhibit either I(1) or I(2), using OLS will results in spurious regression which must be avoided. The stationarity test results are presented in Table 3.

As show in Table 3, all the variables are not stationary in levels but turned stationary after first differencing except log of real GDP that became stationary after second differencing. That is, the variables of this study and both I(1) and I(2). The main implication of these stationarity test results is that it will not be appropriate to use estimate the model using the levels of the variables. It also implies that an ECM estimation technique is feasible for the study. However, to use ECM, the variables must be cointegrated. Therefore, we proceed to test for cointegration among the variables using the Johansen approach. The result from this test is presented in Table 4. 
Table 4: Cointegration test

\begin{tabular}{|c|c|c|c|c|c|}
\hline Null & Alternative & Eigenvalue & LR statistics & 5\% critical value & Probability \\
\hline $\mathrm{r}=0^{*}$ & $\mathrm{r}=1$ & 0.8801 & 146.492 & 95.754 & 0.0000 \\
\hline $\mathrm{r} \leq 1^{*}$ & $\mathrm{r}=2$ & 0.7250 & 89.215 & 69.819 & 0.0007 \\
\hline $\mathrm{r} \leq 2^{*}$ & $\mathrm{r}=3$ & 0.6696 & 54.363 & 47.856 & 0.0108 \\
\hline $\mathrm{r} \leq 3$ & $\mathrm{r}=4$ & 0.4314 & 24.465 & 29.797 & 0.1815 \\
\hline $\mathrm{r} \leq 4$ & $\mathrm{r}=5$ & 0.2747 & 9.223 & 15.495 & 0.3452 \\
\hline $\mathrm{r} \leq 5$ & $\mathrm{r}=6$ & 0.0202 & 0.552 & 3.841 & 0.4576 \\
\hline
\end{tabular}

Source:: Authors' computation from E-Views 10 (2020). (i) $\mathrm{r}$ denotes the number of co-integrating equations, (ii) * denotes rejection of the hypothesis at $5 \%$ level.

As reported in Table 4, the test indicates that there are three cointegrating equations among the variables of the study implying that a long run relationship exists among them and that an error correction mechanism can be applied in the estimation of the model in which the residual from the long run regression is used as error correcting term in the short run model.

Before proceeding to the estimation of the model, it is also necessary to examine the causal relationship between the variables as a way of providing preliminary interactions that exist between them. To do this, the pairwise Granger Causality test was adopted and the results are presented in Table 5.

Table 5: $\quad$ Pairwise Granger causality test (Number of samples: 1990 2018)

\begin{tabular}{|c|c|c|c|c|}
\hline Null Hypothesis & $\begin{array}{c}\text { No. of } \\
\text { Obs*. }\end{array}$ & F-Statistic & Prob.** & Decision \\
\hline EXDT does not Granger Cause CPIA & 27 & 15.3582 & 0.0007 & Rejected \\
\hline CPIA does not Granger Cause EXDT & 27 & 0.35086 & 0.7079 & Accepted \\
\hline FISB does not Granger Cause CPIA & 27 & 2.02235 & 0.1562 & Accepted \\
\hline CPIA does not Granger Cause FISB & 27 & 4.18412 & 0.0288 & Rejected \\
\hline LRGDP does not Granger Cause CPIA & 27 & 0.58631 & \multicolumn{1}{|c|}{0.5648} & Accepted \\
\hline CPIA does not Granger Cause LRGDP & 27 & 0.31333 & \multicolumn{1}{|c|}{0.7342} & Accepted \\
\hline FISB does not Granger Cause EXDT & 27 & 3.89488 & 0.0356 & Rejected \\
\hline EXDT does not Granger Cause FISB & 27 & 2.87979 & 0.0775 & Accepted \\
\hline INFL does not Granger Cause EXDT & 27 & 0.06409 & 0.9381 & Accepted \\
\hline EXDT does not Granger Cause INFL & 27 & 0.38937 & 0.6821 & Accepted \\
\hline LRGDP does not Granger Cause EXDT & 27 & 1.36453 & 0.2763 & Accepted \\
\hline EXDT does not Granger Cause LRGDP & 27 & 0.20189 & 0.8187 & Accepted \\
\hline REXR does not Granger Cause EXDT & 27 & 0.55812 & 0.5802 & Accepted \\
\hline EXDT does not Granger Cause REXR & 27 & 0.06272 & 0.9394 & Accepted \\
\hline REXR does not Granger Cause INFL & 27 & 1.65943 & 0.2132 & Accepted \\
\hline INFL does not Granger Cause REXR & 27 & 10.5283 & 0.0006 & Rejected \\
\hline
\end{tabular}

Source: Authors' computation from E-Views 10 (2020). (1) A probability value less than 0.05 implies the rejection of the null hypothesis; (ii) Variables are as defined in Table 1. Asterisks * and ** refer to the number of observations and probability respectively. 
As shown by the decision column in Table 5, a unidirectional causal relationship exists between external debt and CPIA i.e. with the causality running from external debt to CPIA. Similarly, a unidirectional causal relationship was also found between fiscal balance and CPIA with the causality running from CPIA to fiscal balance. A one-way causal relationship also exists between fiscal balance and external debt and between inflation and exchange rate with the causality running from fiscal balance to external debt and from inflation to real exchange rate. While the relationship found between fiscal balance and external debt is consistent with theory as persistent fiscal deficits swell up the external debt stock, that between inflation and exchange rate is partially theoretical as it is expected that the two macroeconomic variables should cause each other. Other results from the causality test indicate that external debt has no any causal relationship with inflation, real output and exchange rate. This non-causality of external debt with these key variables is a theoretical and is subjected to further examination in the empirical estimation of both the long run and short run model for the study.

We proceed to estimate the long run model with a view to using its residual as the error correction term in the estimation of the short run model. The results from the estimated long run model is presented in Table 6.

Table 6: Long run regression results

\begin{tabular}{|c|c|c|c|c|}
\hline \multirow[b]{2}{*}{ Variables } & \multicolumn{4}{|c|}{ Dependent Variable: LRGDP } \\
\hline & Coefficient & Std. Error & t-statistics & Prob. \\
\hline Constant & 3.313 & 2.955 & 1.121 & 0.274 \\
\hline CPIA & $2.107 *$ & 0.803 & 2.624 & 0.015 \\
\hline EXDT & 0.015 & 0.013 & 1.107 & 0.280 \\
\hline FISB & -0.031 & 0.021 & -1.486 & 0.151 \\
\hline INFL & -0.008 & 0.005 & -1.786 & 0.087 \\
\hline REXR & -0.0007 & 0.0014 & -0.520 & 0.608 \\
\hline $\mathrm{R}^{2}$ & \multicolumn{4}{|c|}{0.501} \\
\hline F. Stat. (Prob) & \multicolumn{4}{|c|}{$4.624(0.004)$} \\
\hline D-W & \multicolumn{4}{|c|}{1.78} \\
\hline
\end{tabular}

Source: Authors' computation from E-Views 10 (2020). Asterisk * denotes that the variable is significant at $5 \%$ level.

As shown in Table 6, external debt and real output, i.e. log of real GDP are positively related in the long run. Specifically, the coefficient of external debt in the 
growth equation is positive but statistically insignificant. It was found from the results that fiscal balance, inflation and exchange rate all affect real output negatively in the long run with these impacts being statistically insignificant. The negative impact of fiscal balance and exchange on real output is not consistent with a priori expectation as deficit financing by government is expected to stimulate growth as posited by the Keynesian demand management hypothesis. Only the coefficient of CPIA is both positive and statistically significant at 5\% level in the long run. The coefficient of determination of 0.501 indicates that about half of the variations in real output is accounted for by the linear influence of all the explanatory variables while the F-Statistics and its probability show that the overall regression is significant at $1 \%$ level.

Having estimated the long run model, we proceed to estimate the short run ECM model using the residual from the former as the error correction term in the latter. The results are presented in Table 7.

From Table 7, as expected, most of the variables in the short run model are either statistically or marginally significant. Also, most of the estimated coefficients of the short run model are consistent with the findings in the long model. Specifically, a statistically insignificant positive relationship was found between external debt and real output. The lag values of exchange rate and fiscal balance impact real output negatively in the short run with the relationship found to be significant at 5\% level. The current exchange rate affect output positively though it is not significant at conventional levels. Current values of inflation also have a negative statistically significant effect on the real output in the short run. Also, lag values of real output positively affect current real output significantly. As in the long run model, current CPIA positively affects current output though not statistically significant. It is however important to note that the error correction term has the correct negative sign but not statistically significant. Also, the speed of adjustment as shown by the coefficient of the error correction term is very low with only $2.57 \%$ of disequilibrium in the short run are corrected and incorporated into the long run relationship. The coefficient of determination in the short run model $\left(\mathrm{R}^{2}\right)$ is higher than that of the long run model with $73.5 \%$ of the variations in real output explained by the influence of all the explanatory variables. 
Table 7: Short run ECM results

\begin{tabular}{ccccc}
\hline & \multicolumn{4}{c}{ Dependent Variable: D(LRGDP) } \\
\cline { 2 - 5 } Variables & Coefficient & Std. Error & t-statistics & Prob. \\
\hline Constant & 0.010 & 0.008 & 1.283 & 0.218 \\
D(LRGDP(-1)) & $0.759^{* *}$ & 0.134 & 5.652 & 0.000 \\
D(CPIA) & 0.125 & 0.068 & 1.843 & 0.084 \\
D(EXDT(-1)) & 0.002 & 0.001 & 1.171 & 0.259 \\
D(FISB(-1)) & $-0.003^{*}$ & 0.001 & -2.156 & 0.047 \\
D(INFL) & $-0.001^{*}$ & 0.0005 & -2.116 & 0.050 \\
D(REXR) & 0.0002 & 0.0001 & 1.526 & 0.147 \\
D(REXR(-1)) & $-0.0002^{*}$ & 0.0001 & -2.076 & 0.051 \\
D(REXR(-2)) & -0.0002 & 0.0001 & -1.749 & 0.099 \\
ECT(-1) & -0.0257 & 0.0177 & -1.447 & 0.167 \\
R ${ }^{2}$ & \multicolumn{4}{c}{0.735} \\
F. Stat. (Prob) & \multicolumn{5}{c}{$2.922(0.003)$} \\
D-W & \multicolumn{5}{c}{2.608} \\
\hline
\end{tabular}

Source: Authors' computation from E-Views 10 (2020). Asterisks ** and * denote variables as being significant at $1 \%$ and $5 \%$ level respectively.

Having presented the results from the empirical analysis, it is also necessary to examine the statistical properties of the estimated ECM model. The model was tested for serial correlation, normality, heteroskedasticity, stability and specification error. The results from these tests are presented in Table 8 .

Table 8: Diagnostic tests

\begin{tabular}{ccc}
\hline Variable & F - value & Prob. \\
\hline Serial Correlation & 3.327 & 0.066 \\
Normality & 0.468 & 0.791 \\
Heteroscedasticity & 0.507 & 0.852 \\
Stability & 1.604 & 0.225 \\
Functional Form & 0.271 & 0.810 \\
\hline
\end{tabular}

Source: Authors' computation from E-Views 10 (2020).

As shown in Table 8, the coefficient of the Breush-Godfrey LM statistics confirm the absence of serial correlation. The Jaque-Bera statistics for the test of residual normality assumption was adequate and indicates that the study cannot reject the 
null hypothesis that the true error terms in the variables are normally distributed assessing from the probability value of 0.791 . Also, the probability value of the heteroscedasticity test shows that the variance of the estimated ECM model is homoscedastic. The Ramsey RESET test for stability indicates that the estimated model is stable over the period of analysis as indicated by the probability value of 0.225 . Overall, the statistical properties of the model show that the model is consistent, efficient and feasible for forecast and policy making.

\section{CONCLUSION AND RECOMMENDATIONS}

Having confirmed that a statistically insignificant positive relationship exists between external debt and economic growth both in the short run and the long run, the missing piece therefore could be the ineffective utilization of debt with accrued debt drawing back its significant impact on economic growth. In view of the problems debt can create, it is important that policy makers note the following:

- The country should consider in-depth the technical side of external debt before being taken.

- External debt should be well managed so as to reap maximally from it, and it should also be time-bound.

- Alternatives to external debt should be considered, like domestic debt and utilization from reserves or investments over foreign debt option.

- Given the findings of this study that debt payment shows a negative significant relation to GDP, further external debt uptake should be considered only if it will enhance Nigeria's trade and investment, with a further view to stimulating the private sector progress and by extension, economic growth.

The notable policy implication of the study was that Nigeria needs to improve its budgetary activities as the most important part of the public finance process. Thus, the whole public management system should be improved upon so that sound debt policy strategy and accountability can be inculcated in the governance system. Greater stability of the local currency through the financial regulatory body $(\mathrm{CBN})$ will also need to be entrenched, while it is as well important for controlled inflation that will see a sustained economic growth. Finally, there is need for further debt relief negotiation to re-enact the experience of 2005 that saw Nigeria's external debt reduced to nearly zero level. 


\section{REFERENCES}

1. Abdullahi, M.M., Abubakar, N.A. and Hassan, S.B. (2015) 'Determining the macroeconomic factors of external debt accumulation in Nigeria: an ARDL bound test approach', Procedia -Social and Behavioral Sciences, 211.745 -752 .

2. Adedoyin, L.I., Babalola, B.M., Otekunri, A.O. and Adeoti, J.O. (2016) 'External debt and economic growth: evidence from Nigeria', Acta Universitatis Danubius (Economica, 12(6).

3. Adegbite, E.O., Ayadi, F.S. and Ayadi, F.O. (2008) 'The impact of Nigeria's external debt on economic development', International Journal of Emerging Markets, 3(3).285- 301.

4. Adepoju, A.A, Salau, A.S. and Obayelu, A.E. (2007) The Effects of External Debt Management on Sustainable Economic Growth and Development: Lessons from Nigeria, Munich Personal RePEC Achieve (MPRA) Paper, No. 2147.

5. Adesola, W.A. (2009) 'Debt servicing and economic growth and public investment: the case of Nigeria', Jurnal of Social Sciences, 8(2).

6. Ajab A.A. and Audu, I. (2006) 'External debt, investment and economic growth: evidence from Nigeria', Central Bank of Nigeria Economic and Financial Review, 44(1).81-113.

7. Alfredo, P. (2002) The Bottom Billion, Oxford University Press, New York.

8. Aluko, F. and Arowolo, D. (2010) 'Foreign aid, the third world debt crisis and the implication for economic development: the Nigerian experience', African Journal of Political Science and International Relations, 4(4). 120-127.

9. Audu, I. (2004) The Impact of External Debt on Economic Growth and Public Investment: The Case of Nigeria, African Institute for Economic Development and Planning (IDEP), Senegal, Dakar.

10. Borensztein, E. (1990) Debt Overhang, Debt Reduction and Investment: The Case of Philippines, International Monetary Fund (IMF), Working Paper, No. $\mathrm{WP} / 90 / 77$.

11. CBN (2012) Annual Statement of Accounts 2012, Central Bank of Nigeria [CBN], Abuja.

12. CBN (2019) Statistical Bulletin, Central Bank of Nigeria [CBN], Abuja.

13. Chenery, H.B. and Strout, A. (1966) 'Foreign assistance and economic development', American Economic Review, 56. 679-733.

14. Chowdhury, A.R. (2001) 'Foreign debt and growth in developing countries', Paper Presented at WIDER Conference on Debt Relief (August), United Nations University, Helsinki. 
15. Chowdhury, A.R. (2004) 'External debt, growth and the HIPC initiative: is the country's choice too narrow? in Addison, T., Hansen, H. and Tarp, F. (Eds.): Debt Relief for Poor Countries. Studies in Development Economics and Policy, Palgrave Macmillan, London.

16. Claessens, S. and Diwan, I. (1990) 'Investment incentives: new money, debt relief, and the critical role of conditionality in debt crisis', The World Bank Economic Review, 4(1).

17. Clements, B., Bhattarcharya, R. and Nguyen, T.Q. (2003) External Debt, Public Investment and Growth in Low Income Countries, IMF Working Paper, No. 03/249.

18. Cohen, D. (1993) 'Low investment and large LCD debt in the 1980s', The American Economic Review, 18(3).

19. Corden, W.M. (1998) The Asian Crisis: Is There a Way Out? Institute of Southeast Asian Studies, Singapore.

20. Davidson, R. and MacKinnon, J.G. (2004) Econometric Theory and Methods, Oxford University Press, New York.

21. Debt Management Office [DMO] (2012) DMO 2011 Annual Report, DMO, Abuja,

22. Debt Management Office [DMO] (2015) DMO 2014 Annual Report, DMO, Abuja,

23. Dijkstra, G., Akanji, B., Hiddink, C., Sangarabalan, S. and de Mevius, F. (2011) Mutual Interests - Mutual Benefits: Evaluation of the 2005 Debt Relief Agreement Between the Paris Club and Nigeria, Evaluation Main Report. Ministry of Foreign Affairs of the Kingdom of the Netherlands.

24. Domar, P. (1987) Clockwork Debt, Lexington Books, Lexington, Massachusetts.

25. Edo, S.E. (2002) 'External debt problem in Africa: a comparative study of Nigeria and Morocco', African Development Review, 14, 221-236.

26. Elbadawi I., Ndulu, B. and Ndung'u, N. (1997) 'Debt overhang and economic growth in sub-Saharan Africa', in Zubair, I. and Kanbur, R. (Eds.): External Finance for Low Income Countries, International Monetary Fund (IMF), Washington D.C.

27. Ezeabasili E.I. (2011) 'Nigeria foreign policy and the politics of debt relief', Canadian Social Science, 7(2), 153-165.

28. Ezeabasili, V.N., Isu, H.O. and Mojekwu, J.N. (2011) 'Nigeria's external debt and economic growth: an error correction approach', International Journal of Business and Management, 6(5). 
29. Fosu, A.K. (2007) The External Debt Servicing Constraint and Public Expenditure Composition: Evidence from African Economies, UNU-WIDER. Research Paper No. 2007/36.

30. Fosu, A.K. (2009) 'The external debt burden and economic growth in the 1980s: evidence from sub-Saharan Africa', Canadian Journal of Development Studies, 20(2),307-318.

31. Giavazzi, F. and Pagano, M. (1990) Can Severe Fiscal Contractions Be Expansionary? Tales of Two Small European Countries, CEPR Discussion Papers, No. 417.

32. Gohar, M., Bhutto, N.A. and Butt, F. (2012) The Impact of External Debt Servicing on the Growth of Low-Income Countries, Sukkur Institute of Business Administration.

33. Greene, E.J. and Khan, S.M. (1990) The African Debt Crisis, Special Paper 3, Initiatives Publishers, African Economic Research Consortium (AERC), Nairobi.

34. Hameed, A., Ashraf, H. and Chaudary, M.A. (2008) 'External debt and its impact on economic and business growth in Pakistan', International Research Journal of Finance and Economics, 20, 132-140.

35. Higgins, B. (1959) Economic Development, Norton, New York.

36. Jhingan, M. L. (2000) The Economics of Development and Planning, 33 $3^{\text {rd }}$ Edition, Vrinda Publications (P) Limited, Delhi.

37. Johansson, P. (2010) 'Debt relief, investment and growth', World Development, 38(9),.1204-16.

38. Krugman, P.R. (1988) 'Financing versus forgiving a debt overhang', Journal of Development Economics, 29. 253-268.

39. Metwally, M. M. and Tamaschke, R. (1994) 'Debts and deficit ceilings, and sustainability of fiscal policies: an intertemporal analysis', Oxford Bulletin of Economics and Statistics, 62(2), 197-221.

40. Moss, T.J. and Chiang, H.S. (2003) The Other Costs of High Debt in Poor Countries: Growth, Policy Dynamics, and Institutions, Center for Global Development, Issue Paper on Debt Sustainability.

41. Mutasa, C. (2003) Regional Integration and Debt in Africa: A Comparative Report of Africa's Regional Groupings, AFRODAD Research Series.

42. Ndund'u, S.N. (1998) Dynamic Impact of External Debt Accumulation on Private Investment and Growth in Africa, IMF Working Paper.

43. Omoh, G. (2011) 'Will Nigeria's new finance minister manage huge domestic debt?', Vanguard Newspaper, 25 August.

44. Pattillo C., Poirson, H.L. and Ricci, H. (2002) External Debt and Growth, IMF Working Paper, Washington, DC. 
45. Pattillo, C. Ricci, H. and Poirson, H. (2004) What are the Channels Through Which External Debt Affects Economic Growth? IMF Working Paper, No. W04/15, Washington, DC.

46. Pearson, L.B. (1969) The Cross of Development, Longman, London.

47. Perlo-Freeman, S. and Webber, D. J. (2009) 'Basic needs, government debt and economic growth', The World Economy, 32(6) May.

48. Perotti, R. (1999) 'Growth, income distribution, and democracy: what the data say', Journal of Economic Growth, 1(2),149 - 187.

49. Rafindadi, A.A. and Musa, A. (2019) 'An empirical analysis of the impact of public debt management strategies on Nigeria's debt profile', International Journal of Economics and Financial Issues, 9(2), 125 - 127.

50. Sachs, J. (1989) 'The debt overhang of developing countries', in Calvo, G.A., Findlay, R. and Kouri, P. (Eds.): Debt Stabilization and Development: Essay in Memory of Carlos Diaz Alejandro, Basil Blackwell, Oxford.

51. Safdari, M. and Mehrizi, M.A. (2011) 'External debt and economic growth in Iran', Journal of Economic and International Finance, 3(5).

52. Saifuddin, Md. (2016) 'Public debt and economic growth: evidence from Bangladesh', Global Journal of Management and Business Research (B): Economics and Commerce, 16(5), 65-73.

53. Solow, R. M. (1956) 'A Contribution to the theory of economic growth', Quarterly Journal of Economics LXX.

54. Soludo C.C. (2003) 'Debt, poverty and inequality', in Okonjo-Iweala, N., Soludo, C.C. and Murtar, M. (Eds.): The Debt Trap in Nigeria, Africa World Press, New Jersey, 23-74.

55. Symond, R.I. (1970) 'Exchange rate flexibility and monetary policy', Journal of Money, Credit and Banking, 3(2).

56. Transparency International (2019) How Corruption Weakens Democracy, Transparency International 29 January.

57. Udoffia, T.D. and Akpanah, E.A. (2016) 'An assessment of the impact of external debt on economic growth of Nigeria', International Journal of Social Sciences, 10(1), 1-27.

58. Udoka, O.C. and Ogege, S. (2012) 'Public debt and the crisis of development in Nigeria: econometric investigation', Asian Journal of Finance \& Accounting, 4(2), 231-243.

59. World Bank (2019a) Country Policy and Institutional Assessment, World Bank.

60. World Bank (2019b) Macroeconomic Management Weakens While Social Inclusion Policies Improve Slightly in Africa's Poorest Countries, World Bank Press Release No: 2020/014/AFR, July 31, 


\section{Rasheed Oyaromade}

Osun State University, Department of Economics, Osogbo, Nigeria rasheed.oyaromade@uniosun.edu.ng

\section{Olayinka Kehinde Binuomoyo}

Lead City University, Department of Economics, Ibadan, Nigeria okbinuomoyo@gmail.com

\section{Akin George Ogunleye}

Osun State University, Department of Economics, Osogbo, Nigeria akin.ogunleye@uniosun.edu.ng

\section{OPASNOSTI FINANCIRANJA DUGOM: VANJSKI DUG I NJEGOVE IMPLIKACIJE NA EKONOMSKI RAST NIGERIJE}

Primljeno: 1. kolovoz, 2021

Prihvaćeno: 10. studeni, 2021

https://doi.org/10.46458/27121097.2021.27.94

\section{Prethodno priopćenje}

\section{Sažetak}

Ovaj rad ispituje utjecaj inozemnog duga na rast nigerijskog gospodarstva između 1990.-2018. godine s ciljem izvlačenja ključnih implikacija za upravljanje gospodarstvom. Nakon što je utvrđeno da su varijable studije nestacionarne po razinama, ali stacionarne nakon prvog diferenciranja te da su također kointegrirane, za analizu je korištena tehnika ispravljanja pogrě̌aka (ECM). Rezultati Grangerovog testa uzročnosti u paru pokazuju da, iako postoji jednosmjerna uzročna veza između fiskalnog salda i inozemnog duga s uzročno-posljedičnim vezama od fiskalnog salda do inozemnog duga, ne postoji uzročna veza između inozemnog duga i stvarne proizvodnje. Iz kratkoročnih ECM i dugoročnih modela utvrđeno je da postoji statistički beznačajan pozitivan odnos između inozemnog duga i realnog outputa kako u kratkom tako $i$ u dugom roku. Statistička svojstva procijenjenog ECM modela pokazuju da je model dosljedan, učinkovit i izvediv za predviđanje i kreiranje politike. Preporuke proizašle iz studije sugeriraju da bi nigerijska vlada trebala poboljšati upravljanje fiskalnom politikom, učvrstiti 
transparentnost i profesionalizam u upravljanju dugom zemlje te da bi veći javni dug trebao biti održivi instrument za gospodarski rast.

Ključne riječi: Nigerija, vanjski dug, ekonomski rast, devizni tečaj, ECM

JEL: F34, H6, H63 